\title{
Characterizing Adduct Formation of Electrophilic Skin Allergens with Human Serum Albumin and Hemoglobin
}

Lorena Ndreu ${ }^{\dagger}$, Luke N. Erber $^{\ddagger, \S}$, Margareta Törnqvist ${ }^{\dagger}$, Natalia Y. Tretyakova ${ }^{\ddagger}$, , Isabella Karlsson ${ }^{\dagger *}$

†Department of Environmental Science, Stockholm University, SE-106 91 Stockholm, Sweden ‡Department of Medicinal Chemistry, University of Minnesota, Minneapolis, Minnesota 55455, United States

§Masonic Cancer Center, University of Minnesota, Minneapolis, Minnesota 55455, United States

*Corresponding Author:

Email: Isabella.Karlsson@aces.su.se

Phone: +46-(0)721-489 271 


\section{Contents}

Confirmed adducted sites.

Table S1. Peptide sequence and confirmed adducted site for all haptens tested with HSA, namely DNCB, PGE and MDBGN.

Table S2. Peptide sequence and confirmed adducted site for all haptens tested with $\mathrm{Hb}$, namely DNCB and PGE.

Reaction mechanism of the different haptens tested

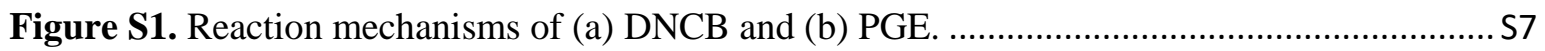

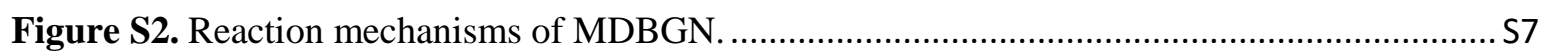

Direct Peptide Reactivity Assay (DPRA) for MDBGN........................................................................... 8

Figure S3. Total Ion Chromatogram (TIC) of the reaction mixture of the peptide Ac-PHCKRM and MDBNG at time point 0 , and the MS/MS spectra of the peak corresponding to the peptide showing the complete dimerization of the initial peptide at retention time $2.3 \mathrm{~min}$. The rest of the peaks in the chromatogram are attributed to impurities also observed in the blank and control runs.

Figure S4. Formation of the adducted peptide Ac-PHCKRM during incubation with standard MDBGN and reduced GSH, over the rate of 24 hours.

Figure S5. Depletion of the peptide Ac-PHCKRM during incubation with standard 2-MGN, over the course of 24 hours, expressed in $\mu \mathrm{M}$.

Figure S6. Formation of the adducted peptide Ac-PHCKRM during incubation with standard 2-

MGN, over the rate of 24 hours.

Figure S7. Reaction scheme of MDBGN with F-moc-Lys including activation by GSH.

Figure S8. Fragmentation pattern of (a) F-moc-Lys and (b) reaction product of F-moc-Lys with MDBGN activated by GSH.

Relative quantitative estimation of modified peptides

Figure S9. Tandem mass spectra, structure of the adducted peptide identified using PRM analysis, and relative estimation of the peptide containing the $\mathrm{Cys}_{90}$ site in HSA modified by PGE.

Figure S10. Tandem mass spectra, structure of the adducted peptide identified using PRM analysis, and relative estimation of the peptide containing the Cys ${ }_{177}$ site in HSA modified by PGE. S11

Figure S11. Tandem mass spectra, structure of the adducted peptide identified using PRM analysis, and relative estimation of the peptide containing the $\mathrm{Cys}_{34}$ site in HSA modified by DNCB. S12

Figure S12. Tandem mass spectra, structure of the adducted peptide identified using PRM analysis, and relative estimation of the peptide containing the Cys 90 site in HSA modified by DNCB. S12

Figure S13. Tandem mass spectra, structure of the adducted peptide identified using PRM analysis, and relative estimation of the peptide containing the Cys 477 site in HSA modified by DNCB. .....S13

Figure S14. Tandem mass spectra, structure of the adducted peptide identified using PRM analysis containing the Lys190 site in HSA modified by DNCB.

Figure S15. Tandem mass spectra, structure of the adducted peptide identified using PRM analysis containing the Lys199 site in HSA modified by DNCB. S14

Figure S16. Tandem mass spectra, structure of the adducted peptide identified using PRM analysis, and relative estimation of the peptide containing the $\mathrm{Val}_{1}$ site in subunit $\alpha$ of $\mathrm{Hb}$ modified by PGE. 
Figure S17. Tandem mass spectra, structure of the adducted peptide identified using PRM analysis, and relative estimation of the peptide containing the His $5_{50}$ site in subunit $\alpha$ of $\mathrm{Hb}$ modified by PGE.

Figure S18. Tandem mass spectra, structure of the adducted peptide identified using PRM analysis, and relative estimation of the peptide containing the $\mathrm{His}_{72}$ site in subunit $\alpha$ of $\mathrm{Hb}$ modified by PGE.

Figure S19. Tandem mass spectra, structure of the adducted peptide identified using PRM analysis, and relative estimation of the peptide containing the His ${ }_{97}$ site in subunit $\mathrm{b}$ of $\mathrm{Hb}$ modified by PGE.

Figure S20. Tandem mass spectra, structure of the adducted peptide identified using PRM analysis, and relative estimation of the peptide containing the $\mathrm{Val}_{1}$ site in subunit $\mathrm{b}$ of $\mathrm{Hb}$ modified by

DNCB.

Figure S21. Tandem mass spectra, structure of the adducted peptide identified using PRM analysis, and relative estimation of the peptide containing the $\mathrm{Cys}_{112}$ site in subunit $\mathrm{b}$ of $\mathrm{Hb}$ modified by

DNCB.

Protein Data Bank (PDB) structures of the adducted proteins

Figure S22. PDB structure of HSA front and back, with sites modified by DNCB highlighted in red.

Figure S23. PDB structure of HSA front and back, with sites modified by PGE highlighted in blue.

Figure S24. PDB structure of HSA front and back, with sites modified by MDBGN highlighted in orange.

Figure S25. PDB structure of Hb front and back, with sites modified by DNCB highlighted in red.

Figure S26. PDB structure of $\mathrm{Hb}$ front and back, with sites modified by PGE highlighted in blue. 


\section{Confirmed adducted sites}

Table S1. Peptide sequence and confirmed adducted site for all haptens tested with HSA, namely DNCB, PGE and MDBGN.

\begin{tabular}{|c|c|c|c|c|}
\hline Peptide Sequence & $\begin{array}{c}\text { Target Amino } \\
\text { acid }\end{array}$ & DNCB & PGE & MDBGN \\
\hline LQQㅌPFEDHVK & Cys34 & $\mathrm{x}$ & $x$ & \\
\hline TCVADESAENC彑DK & Cys62 & $x$ & & $\mathrm{x}$ \\
\hline 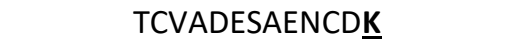 & Lys 64 & & $\mathrm{x}$ & \\
\hline LCGTVATLR & Cys75 & $x$ & & \\
\hline 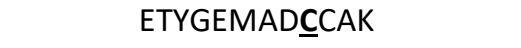 & Cys9o & $\mathrm{X}$ & $x$ & $\mathrm{x}$ \\
\hline ETYGEMADCㅡA & Cys91 & $\mathrm{x}$ & & $x$ \\
\hline AACELLPK & Cys 177 & & $x$ & $x$ \\
\hline (LDELR)DEGㅡASSAK & Lys 190 & $\mathrm{x}$ & $\mathrm{X}$ & \\
\hline LKCASLQKFGER & Lys 199 & $\mathrm{X}$ & & \\
\hline VHTECCHGDLLECADDR & Cys245 & & & $x$ \\
\hline ICEENQDSISSK & Cys265 & & & $\mathrm{x}$ \\
\hline ECCEEKPLLEK & Cys279 & & & $x$ \\
\hline SHCIAEVENDEMPADLPSLAADFVESK & Cys289 & & & $x$ \\
\hline CCAAADPHE $\underline{C}$ & CyS369 & & & $x$ \\
\hline TKKKVPQVSTPTLVEVSR & LyS414 & $x$ & & \\
\hline YTKKVPQVㅍTPTLVEVSR & $\operatorname{Ser}_{419}$ & $x$ & & \\
\hline NLGKKVGSK & Lys 432 & $x$ & & \\
\hline CㅡTESLVNR & Cys477 & $\mathrm{X}$ & & \\
\hline
\end{tabular}


Table S2. Peptide sequence and confirmed adducted site for all haptens tested with $\mathrm{Hb}$, namely DNCB and PGE.

\begin{tabular}{|c|c|c|c|}
\hline Peptide Sequence & Target Amino acid & DNCB & PGE \\
\hline$\underline{\text { VLSPADKTNVK }}$ & $\mathrm{Val}_{1} / \alpha$ & & $x$ \\
\hline VGA & $\mathrm{His} 20 / \alpha$ & & $x$ \\
\hline VGAHAGEYGGAEALER & $\mathrm{Tyr}_{24} / \alpha$ & $x$ & $x$ \\
\hline TYFPHFDLSHGSAQVK & $\mathrm{His} 45 / \alpha$ & & $x$ \\
\hline TYFPHFDLSㅂGSAQVK & $\mathrm{His}_{50} / \alpha$ & & $x$ \\
\hline VADALTNAVA & $\mathrm{His}_{72} / \alpha$ & & $x$ \\
\hline VADALTNAVAHVDDMPNALSALSDLLHAHK & $\operatorname{Ser}_{84} / \alpha$ & & $x$ \\
\hline$\underline{\text { VHLTPEEK }}$ & $\mathrm{Val}_{1} / \beta$ & $x$ & \\
\hline VLGAFSDGLAㅂLDNLK & $\mathrm{His} 77 / \beta$ & & $x$ \\
\hline GTFATLSEELHCDK & Ser $89 / \beta$ & & $x$ \\
\hline GTFATLSELHCDDK & $\mathrm{Cys}_{93} / \boldsymbol{\beta}$ & $x$ & \\
\hline GTFATLSELHCD $\underline{K}$ & Lys95/ $\beta$ & $x$ & \\
\hline
\end{tabular}


LHVDPENFR

LLGNVLVCVLAHHFGK

LLGNVLVCVLAHHFGK

VVAGVANALAHK

VVAGVANALAHK
His97/ $\beta$

Cys $_{112} / \beta$

$X$

$\operatorname{His}_{116} / \beta$

$x$

$\mathrm{His}_{143} / \beta$

$x$

Lys $144 / \beta$

X 
(a)<smiles>[R]NCCCC1(Cl)CC=C([N+](=O)[O-])C=C1[N+](=O)[O-]</smiles>

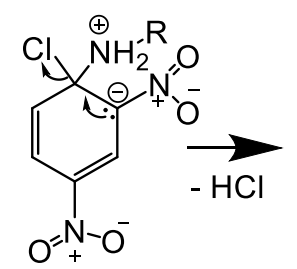

$\mathrm{O}=\mathrm{N}-\mathrm{O}^{-}$<smiles>[R]Nc1ccc([N+](=O)[O-])cc1[N+](=O)[O-]</smiles>

(b)

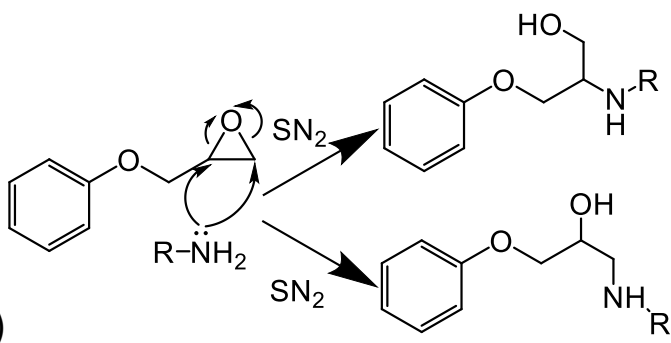

Figure S1. Reaction mechanisms of (a) DNCB and (b) PGE.

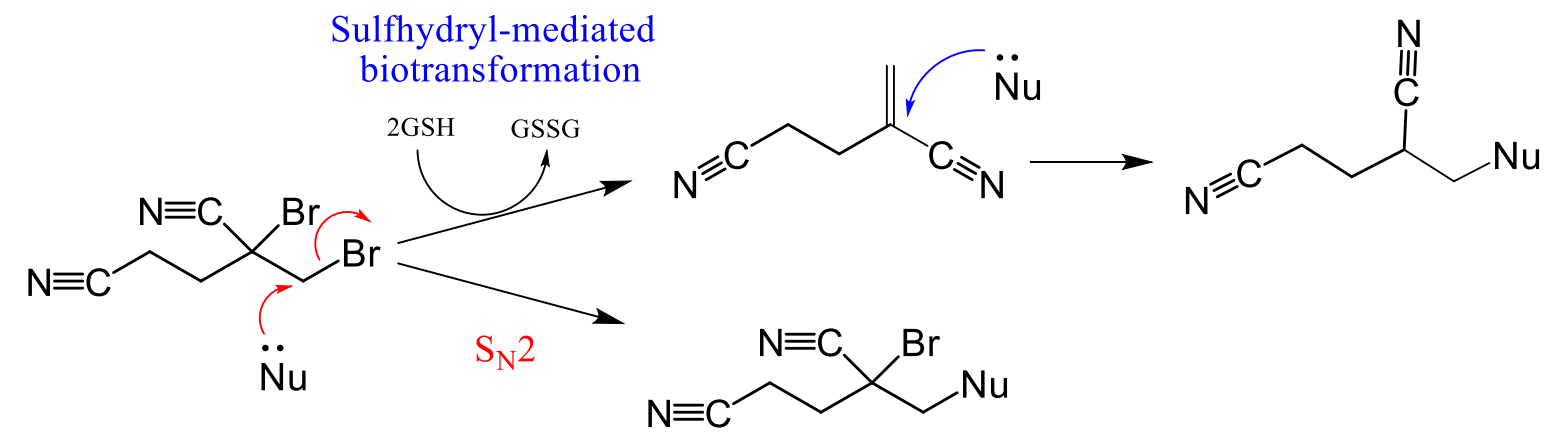

Figure S2. Reaction mechanisms of MDBGN. 


\section{Direct Peptide Reactivity Assay (DPRA) for MDBGN}

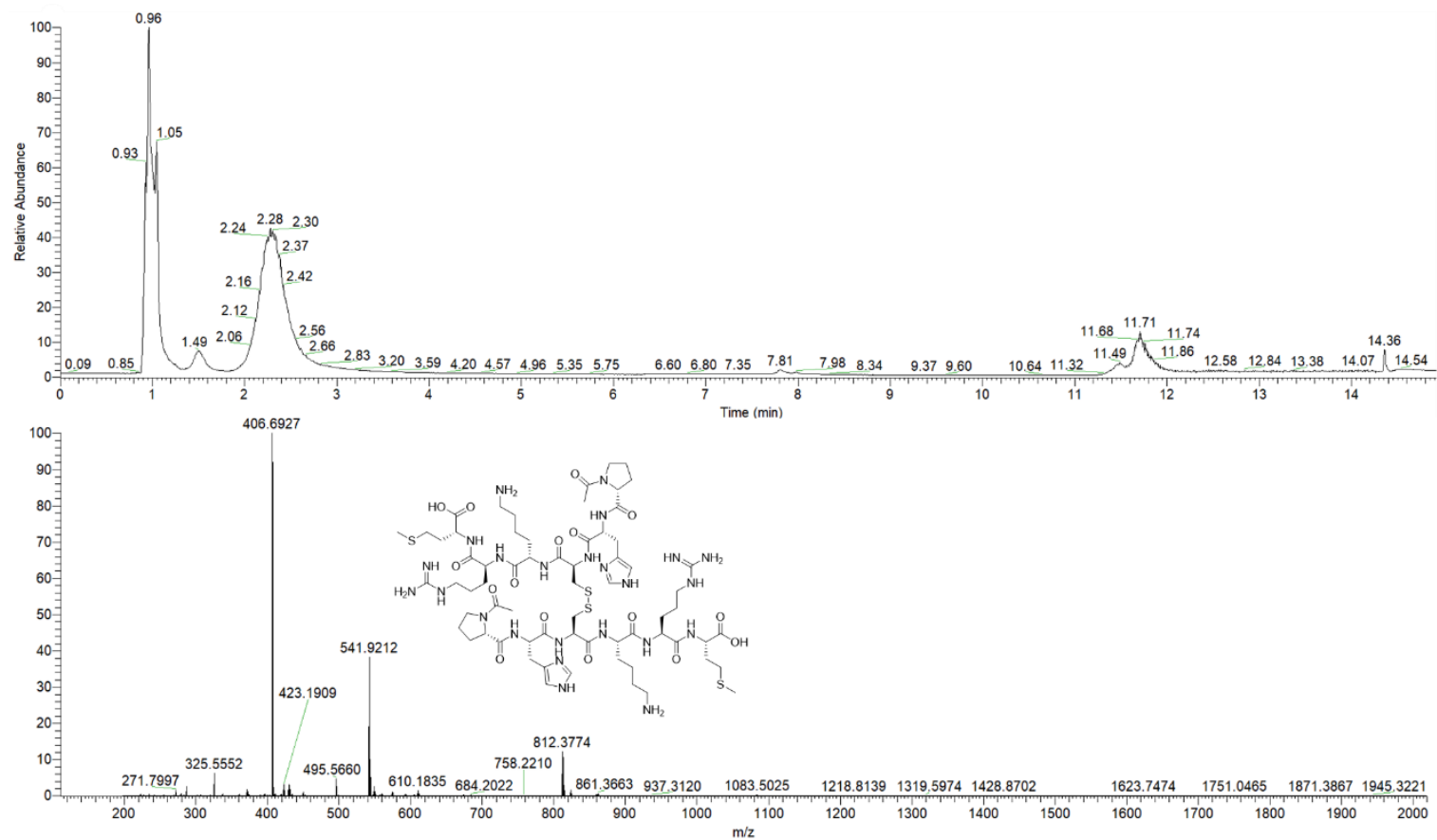

Figure S3. Total Ion Chromatogram (TIC) of the reaction mixture of the peptide Ac-PHCKRM and MDBNG at time point 0 , and the MS/MS spectra of the peak corresponding to the peptide showing the complete dimerization of the initial peptide at retention time $2.3 \mathrm{~min}$. The rest of the peaks in the chromatogram are attributed to impurities also observed in the blank and control runs.

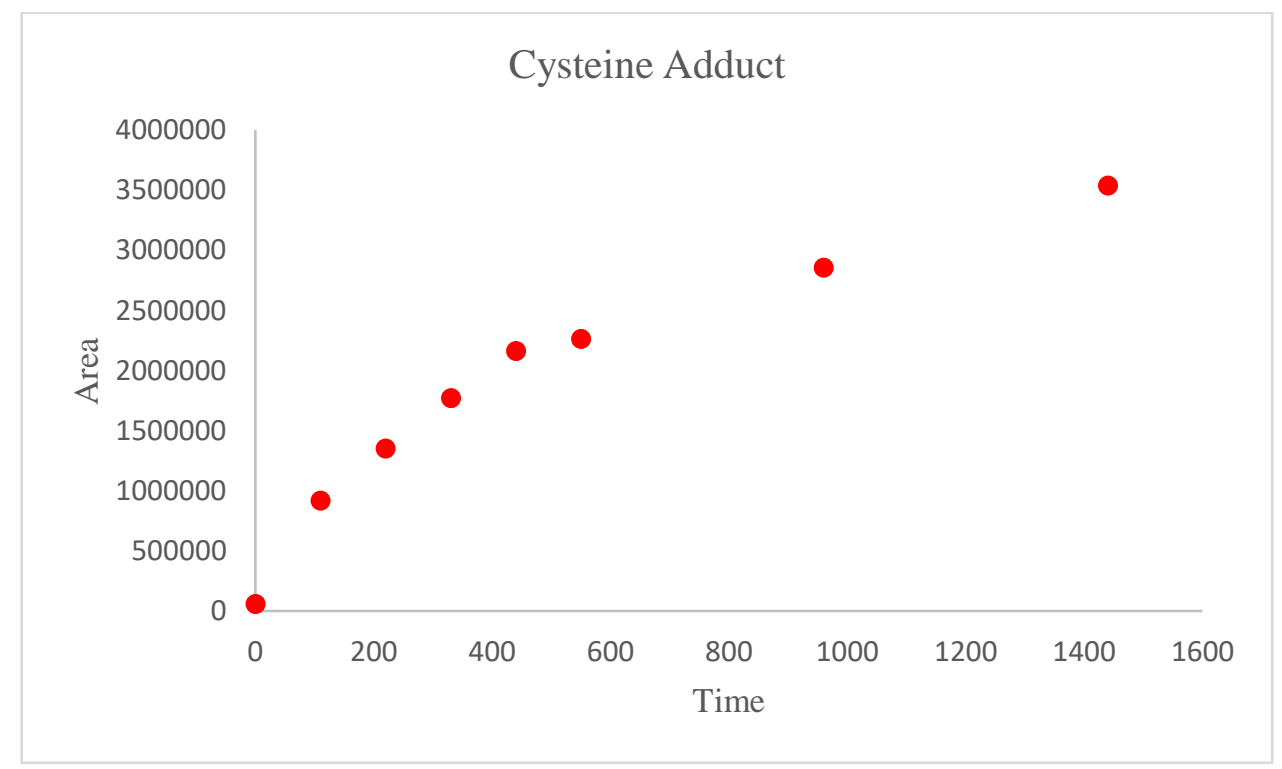

Figure S4. Formation of the adducted peptide Ac-PHCKRM during incubation with standard MDBGN and reduced GSH, over the rate of 24 hours. 


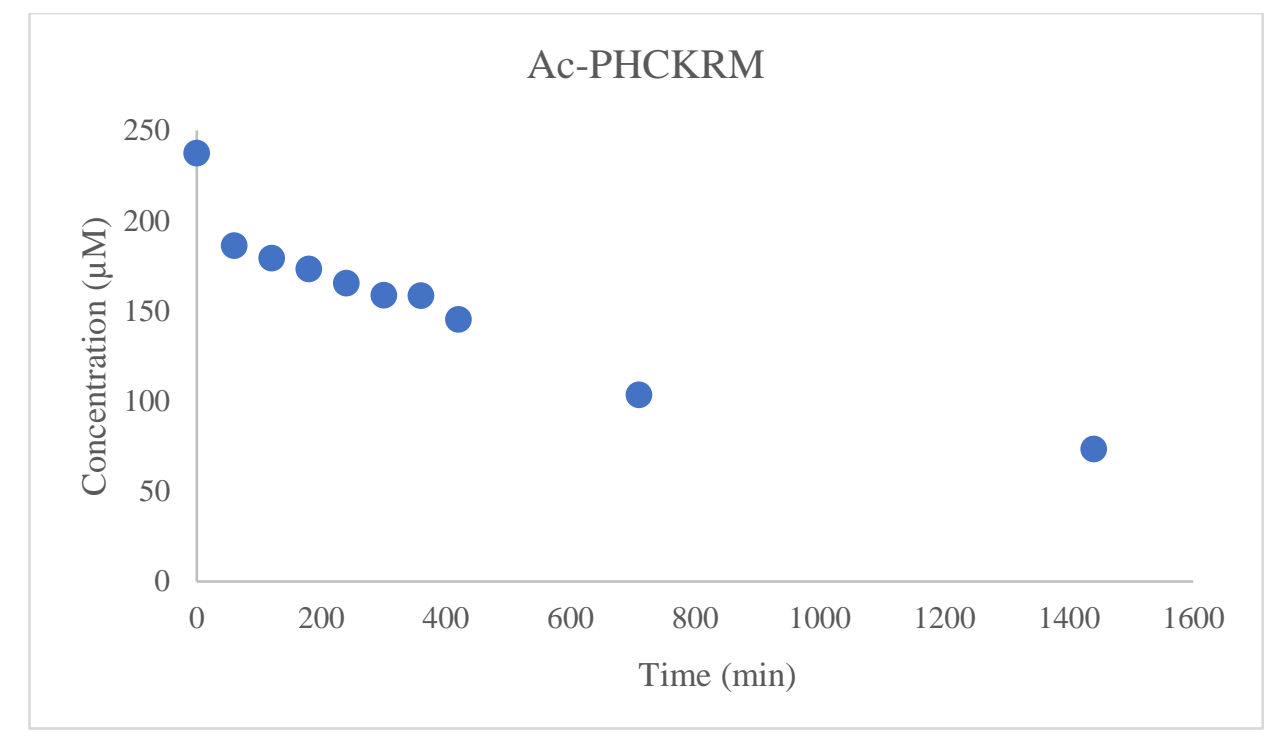

Figure S5. Depletion of the peptide Ac-PHCKRM during incubation with standard 2-MGN, over the course of 24 hours, expressed in $\mu \mathrm{M}$.

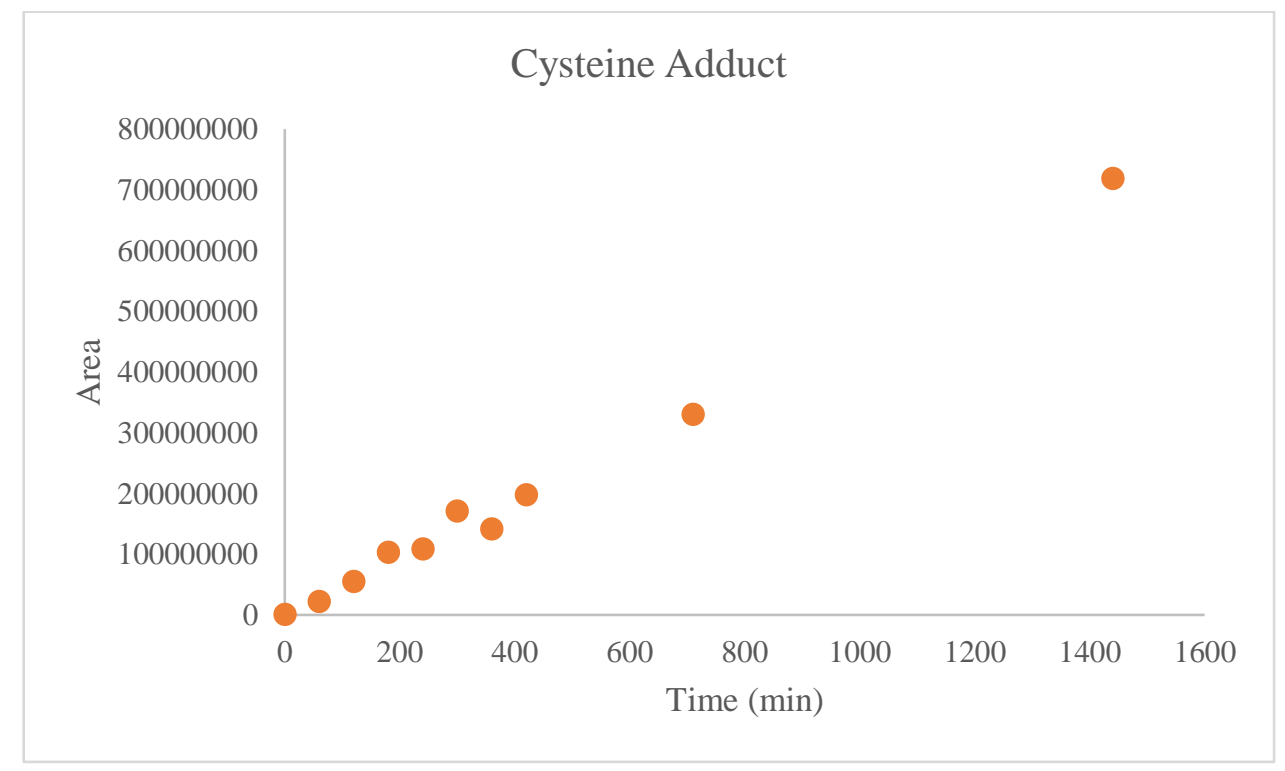

Figure S6. Formation of the adducted peptide Ac-PHCKRM during incubation with standard 2-MGN, over the rate of 24 hours.

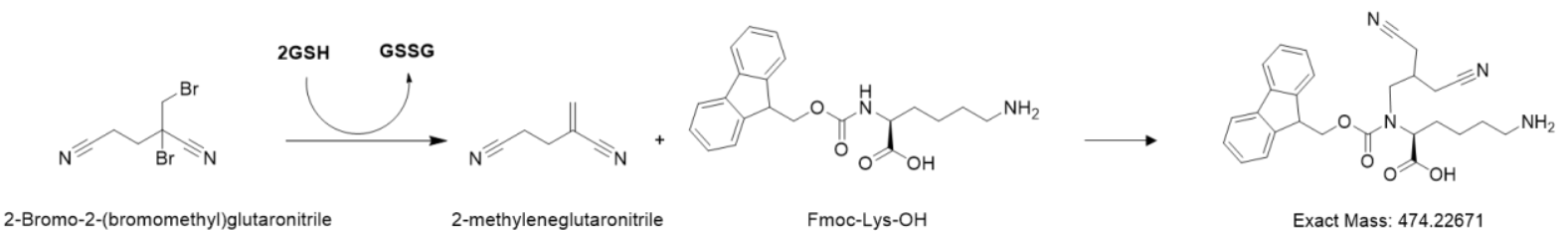

Figure S7. Reaction scheme of MDBGN with F-moc-Lys including activation by GSH. 


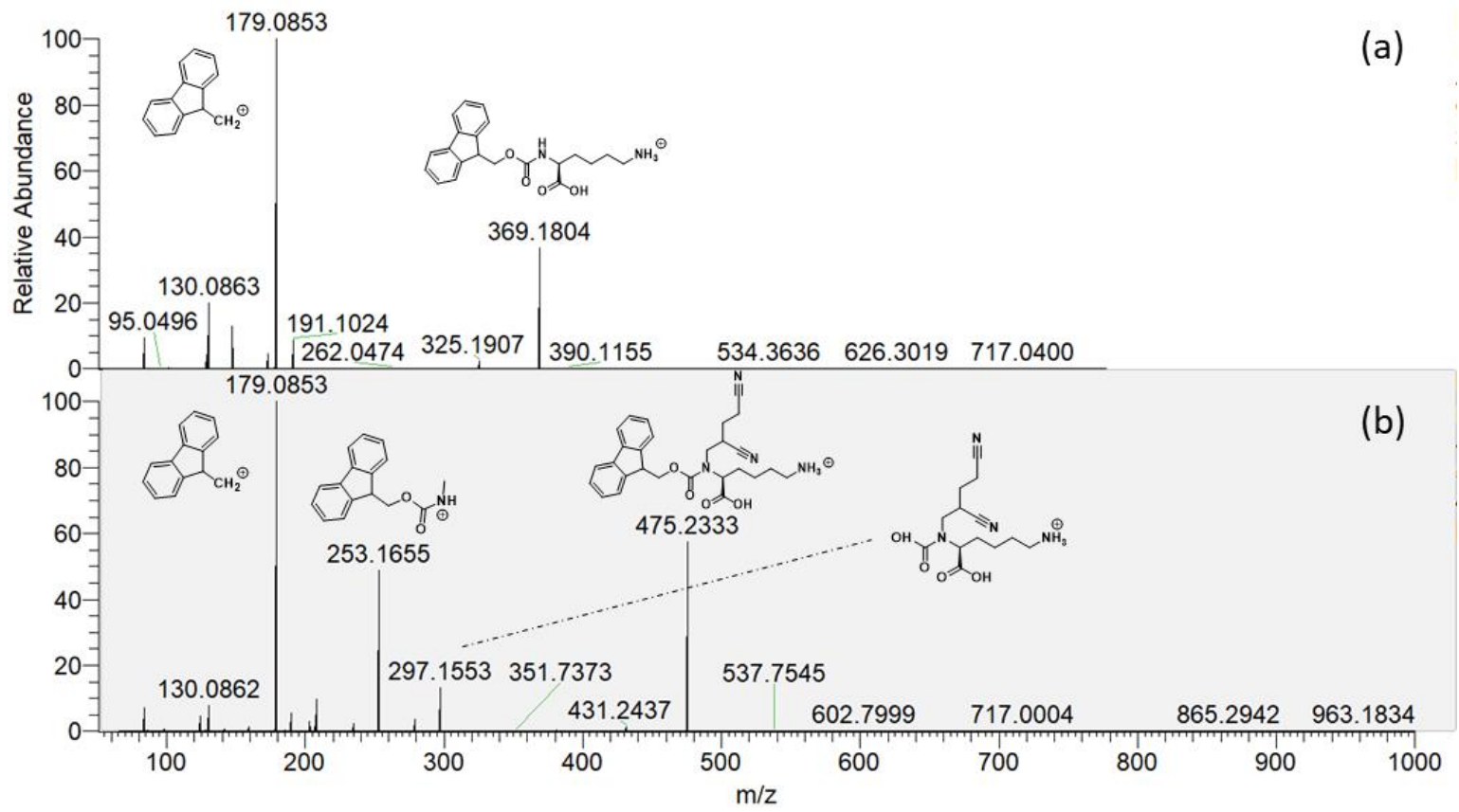

Figure S8. Fragmentation pattern of (a) F-moc-Lys and (b) reaction product of F-moc-Lys with MDBGN activated by GSH. 


\section{Relative quantitative estimation of modified peptides}
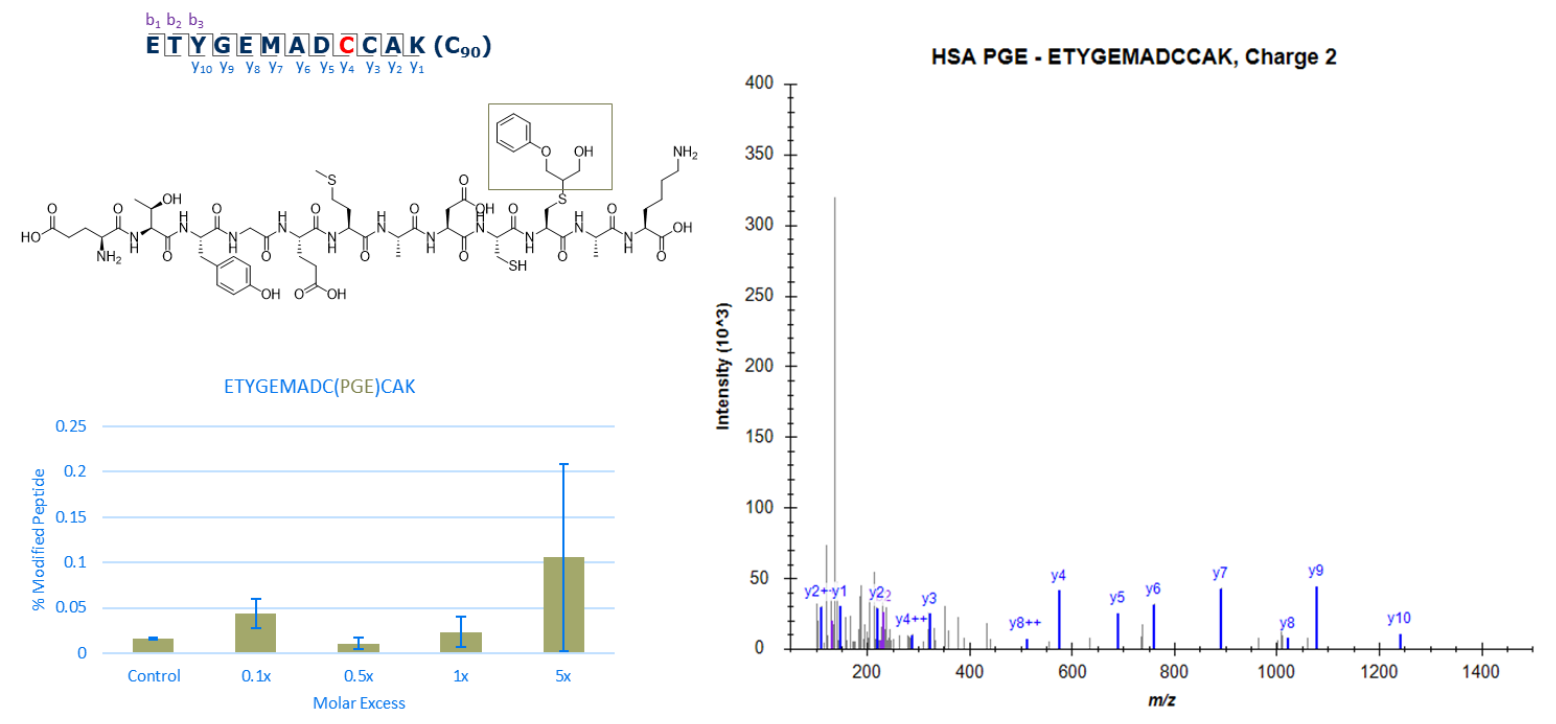

Figure S9. Tandem mass spectra, structure of the adducted peptide identified using PRM analysis, and relative estimation of the peptide containing the Cys90 site in HSA modified by PGE.
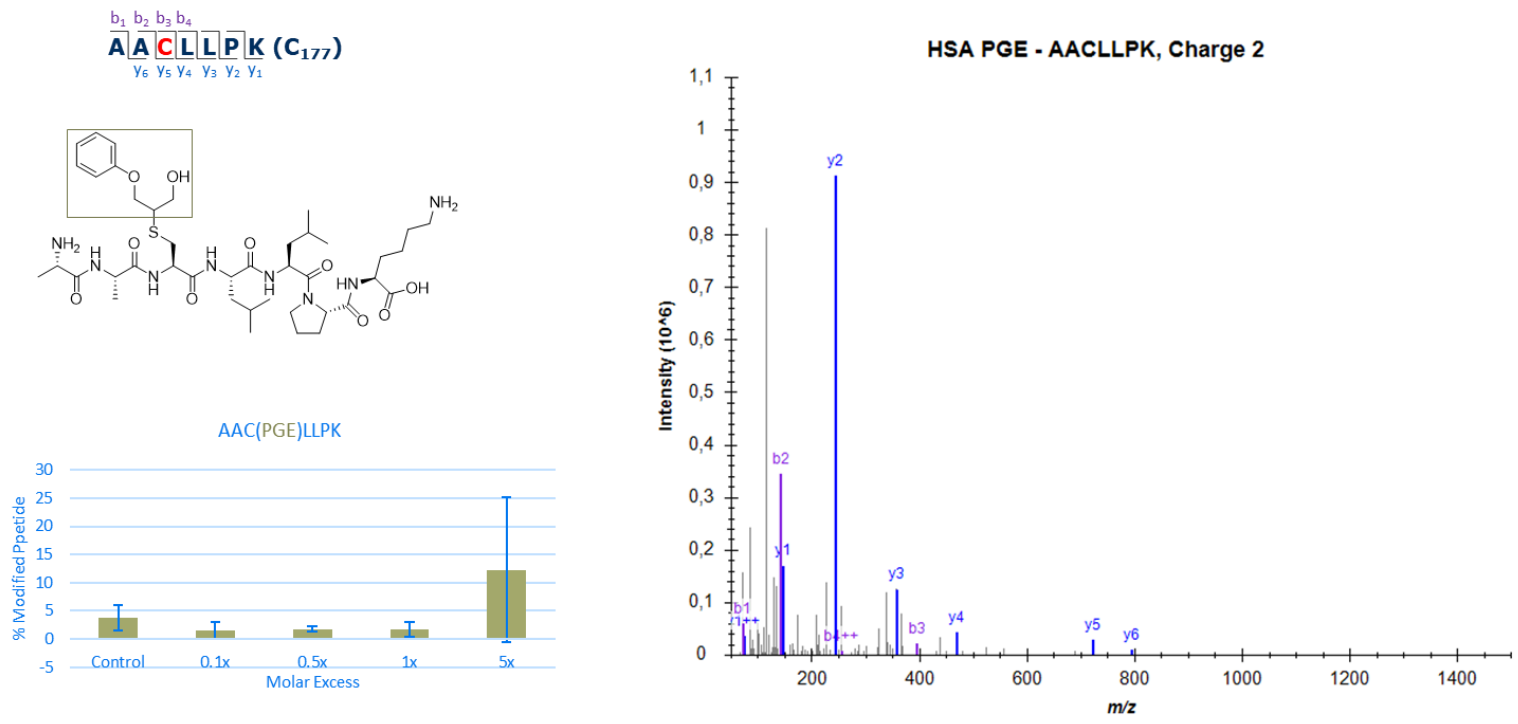

Figure S10. Tandem mass spectra, structure of the adducted peptide identified using PRM analysis, and relative estimation of the peptide containing the Cys 177 site in HSA modified by PGE. 

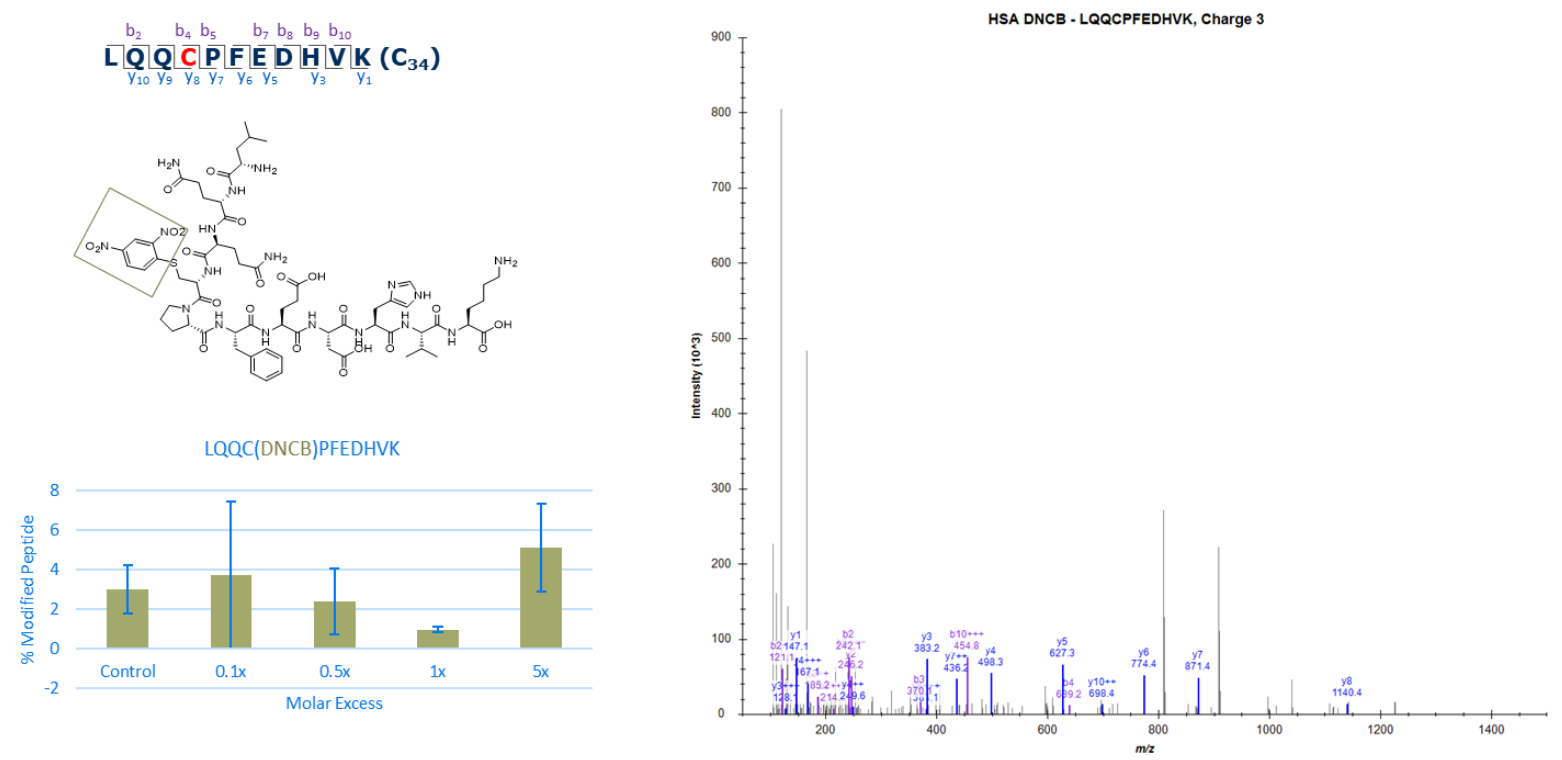

Figure S11. Tandem mass spectra, structure of the adducted peptide identified using PRM analysis, and relative estimation of the peptide containing the $\mathrm{Cys}_{34}$ site in HSA modified by DNCB.

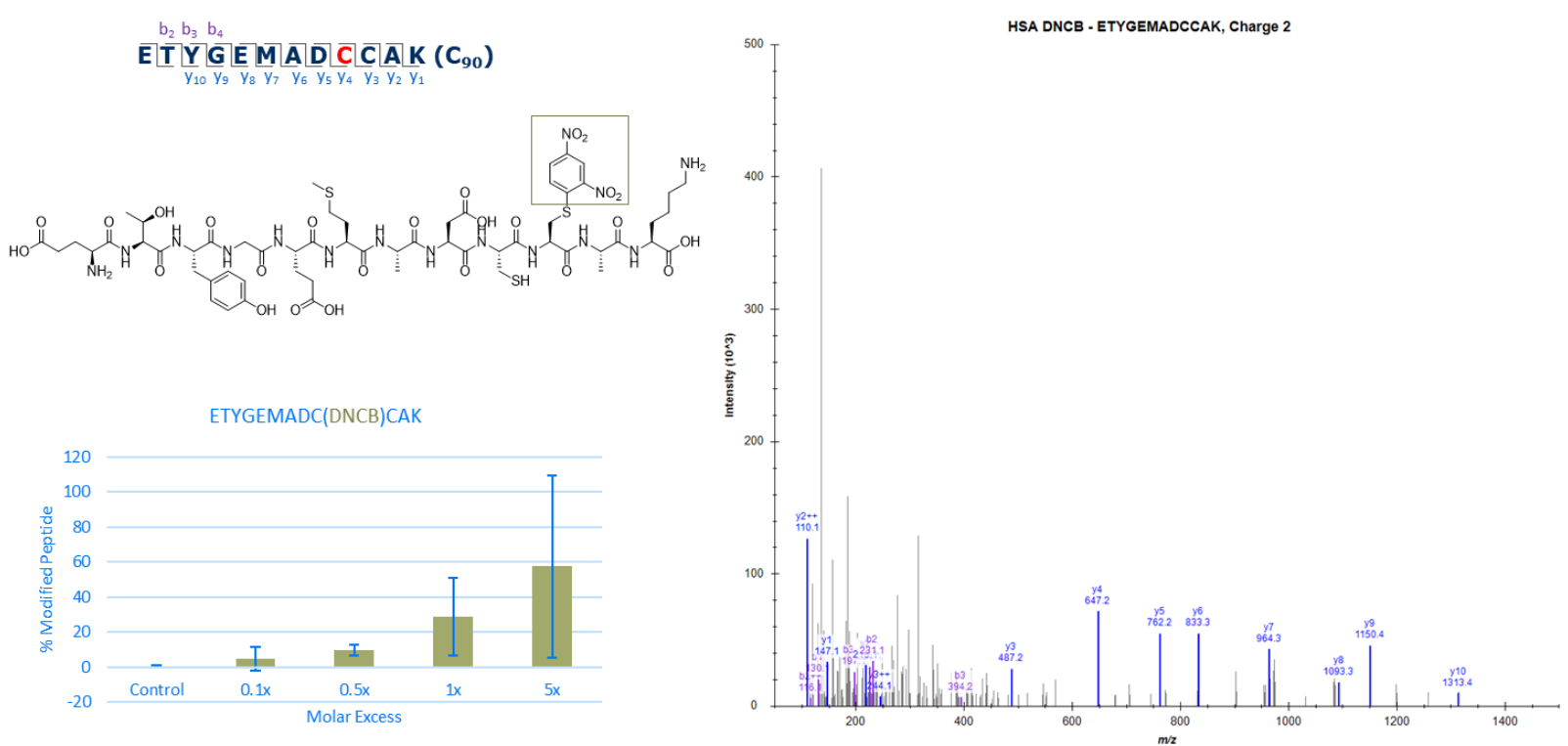

Figure S12. Tandem mass spectra, structure of the adducted peptide identified using PRM analysis, and relative estimation of the peptide containing the Cys90 site in HSA modified by DNCB. 

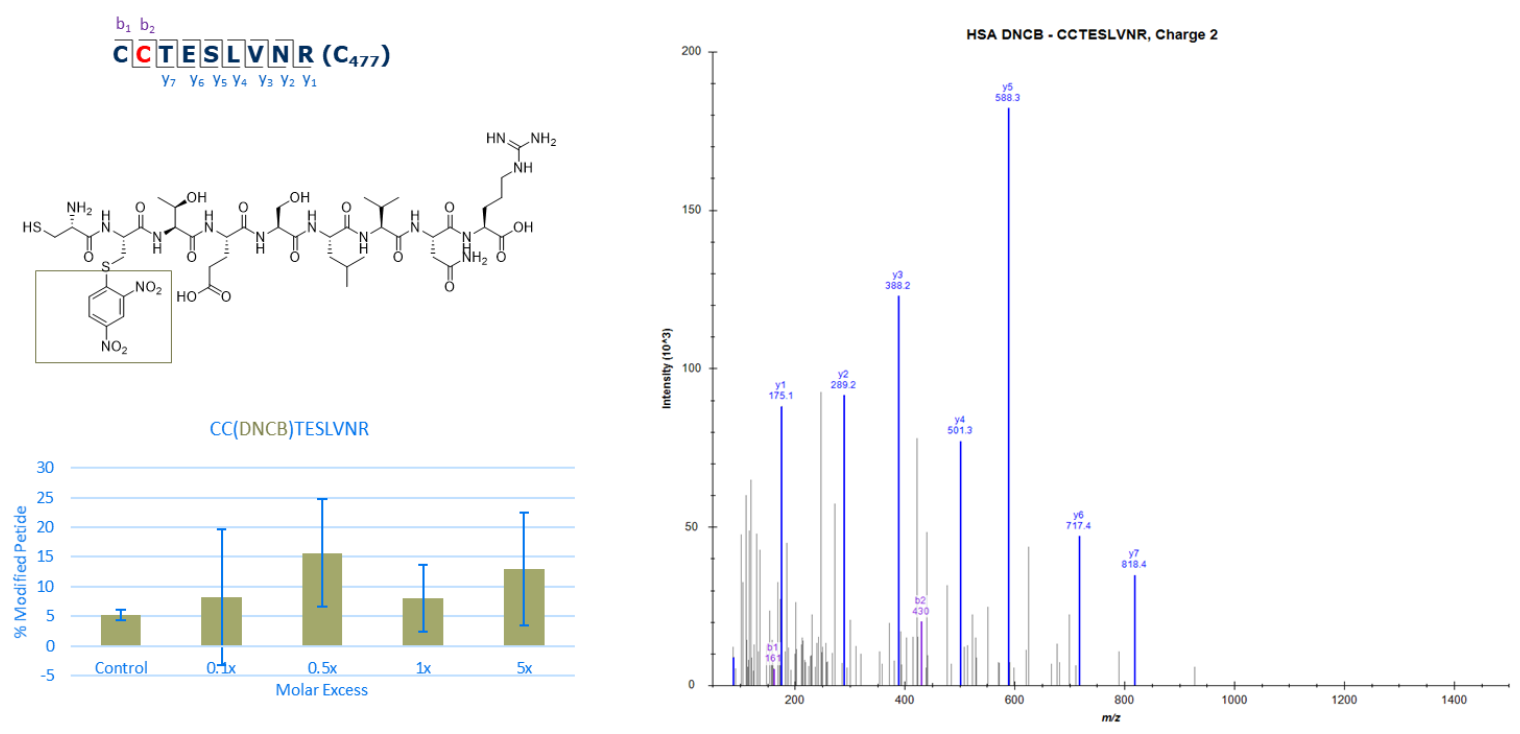

Figure S13. Tandem mass spectra, structure of the adducted peptide identified using PRM analysis, and relative estimation of the peptide containing the Cys477 site in HSA modified by DNCB.
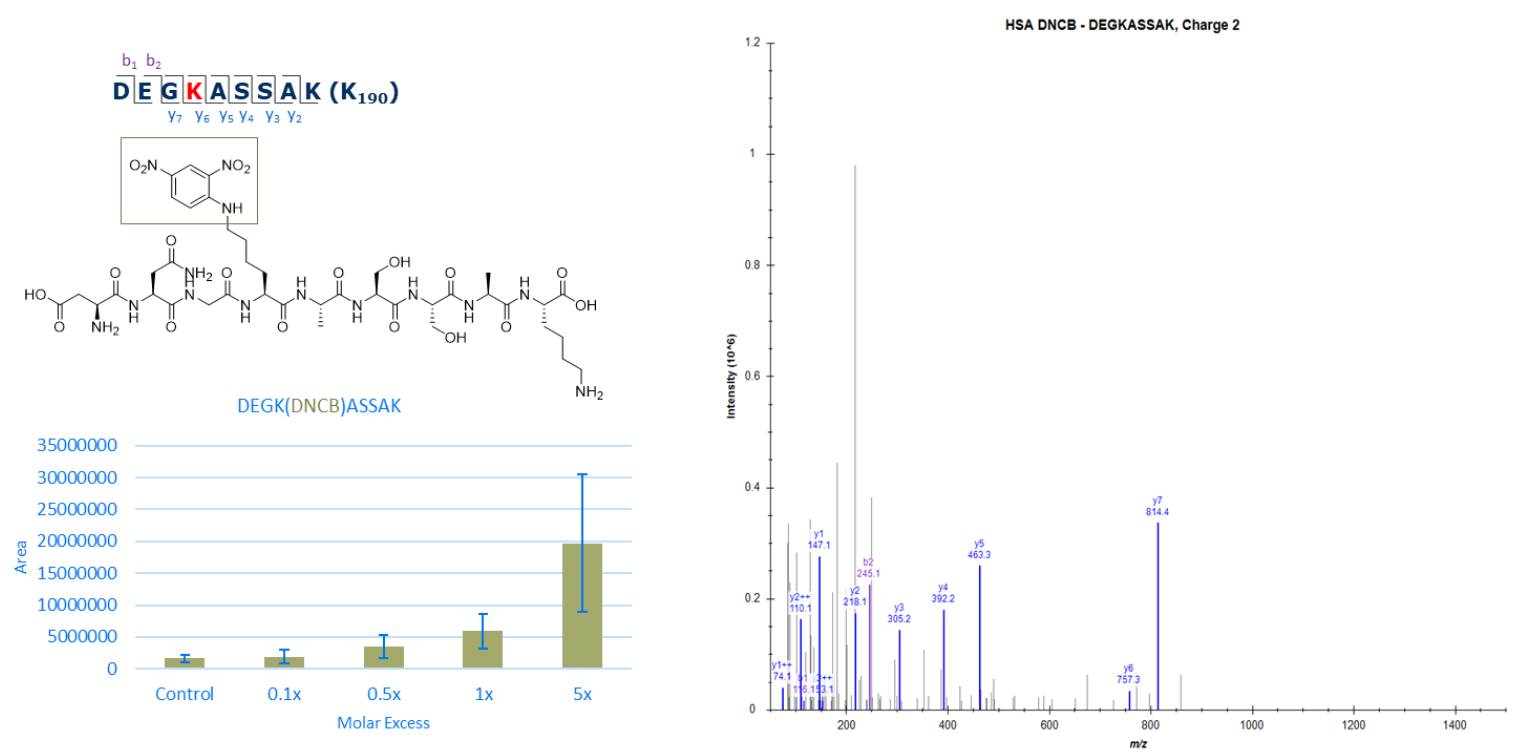

Figure S14. Tandem mass spectra, structure of the adducted peptide identified using PRM analysis containing the Lys190 site in HSA modified by DNCB. 

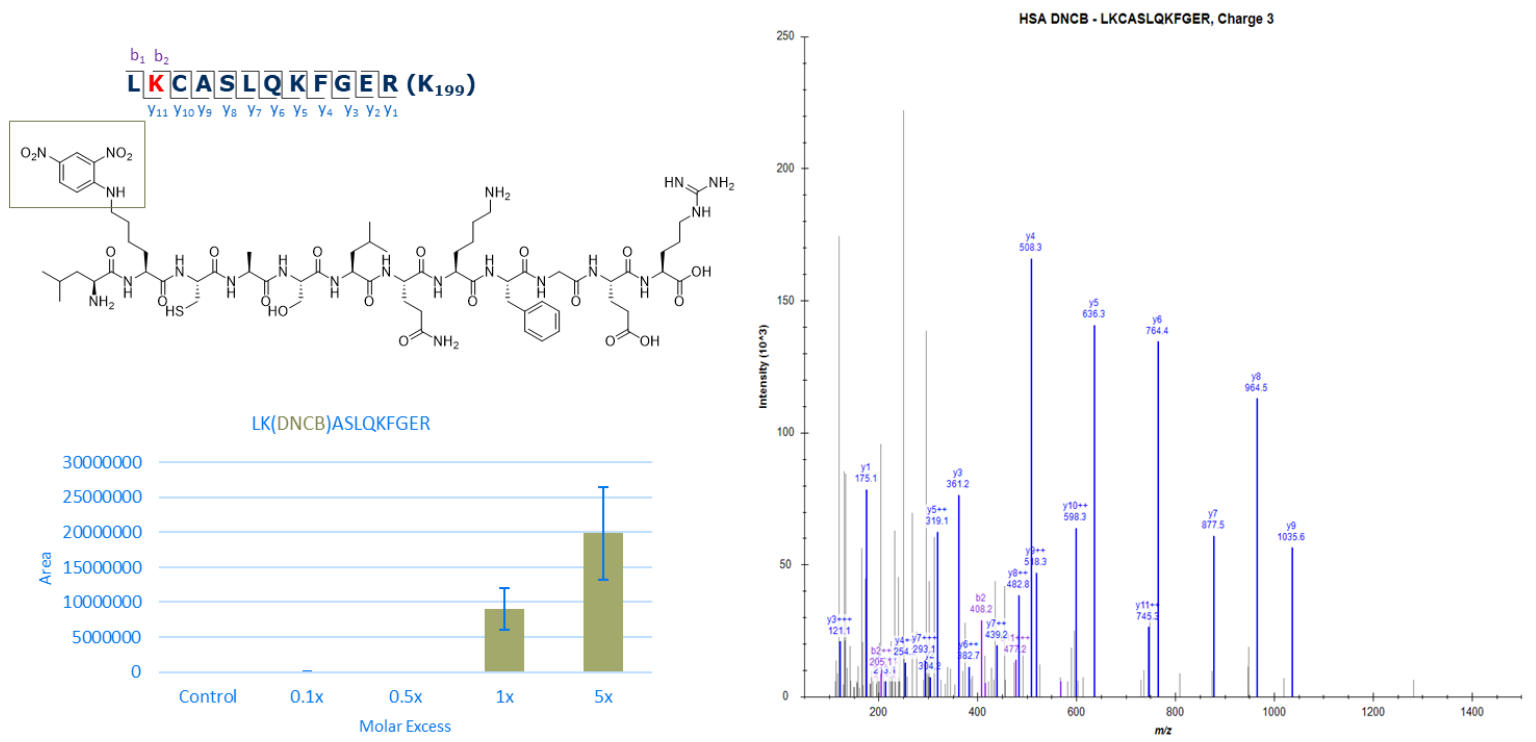

Figure S15. Tandem mass spectra, structure of the adducted peptide identified using PRM analysis containing the Lys199 site in HSA modified by DNCB.
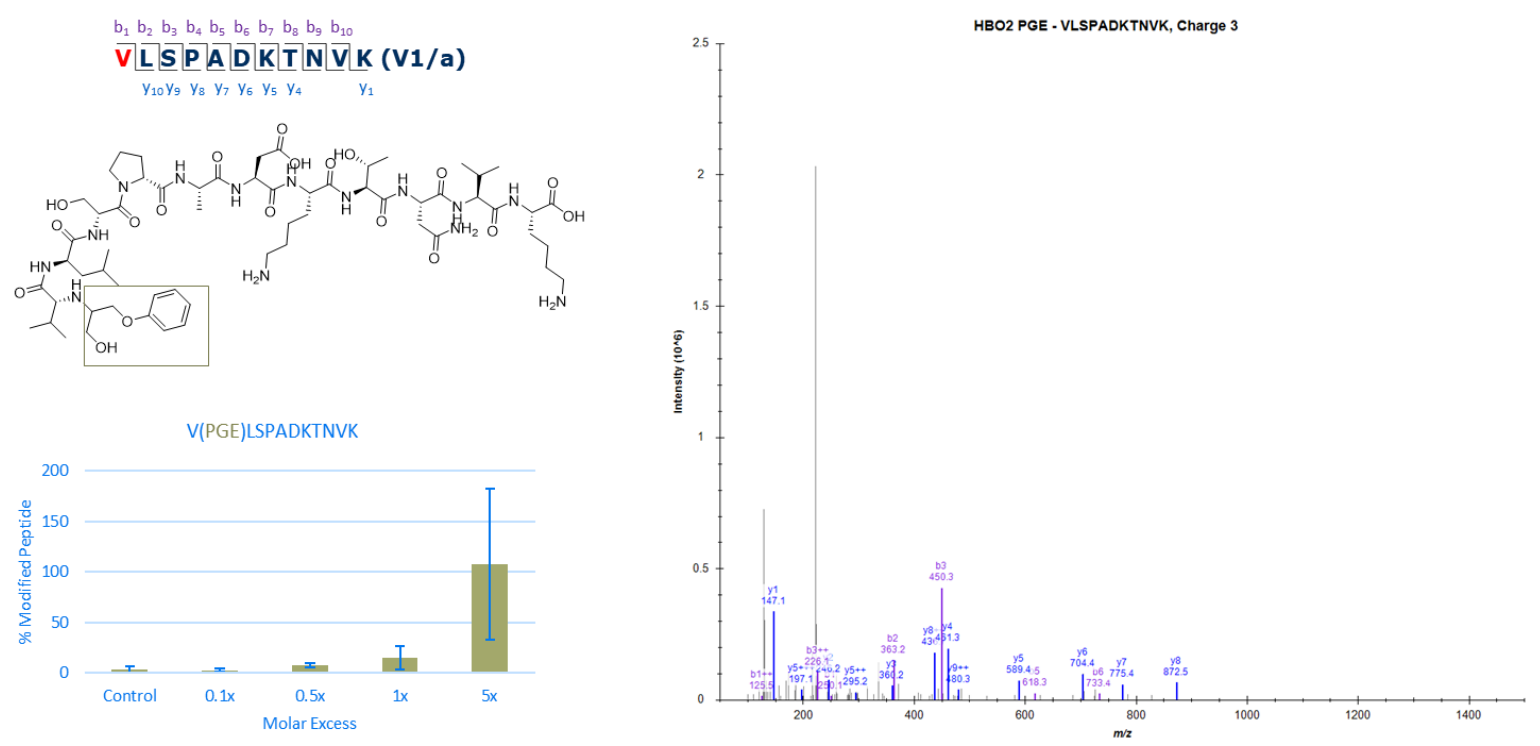

Figure S14. Tandem mass spectra, structure of the adducted peptide identified using PRM analysis, and relative estimation of the peptide containing the $\mathrm{Val}_{1}$ site in subunit $\alpha$ of $\mathrm{Hb}$ modified by PGE. 

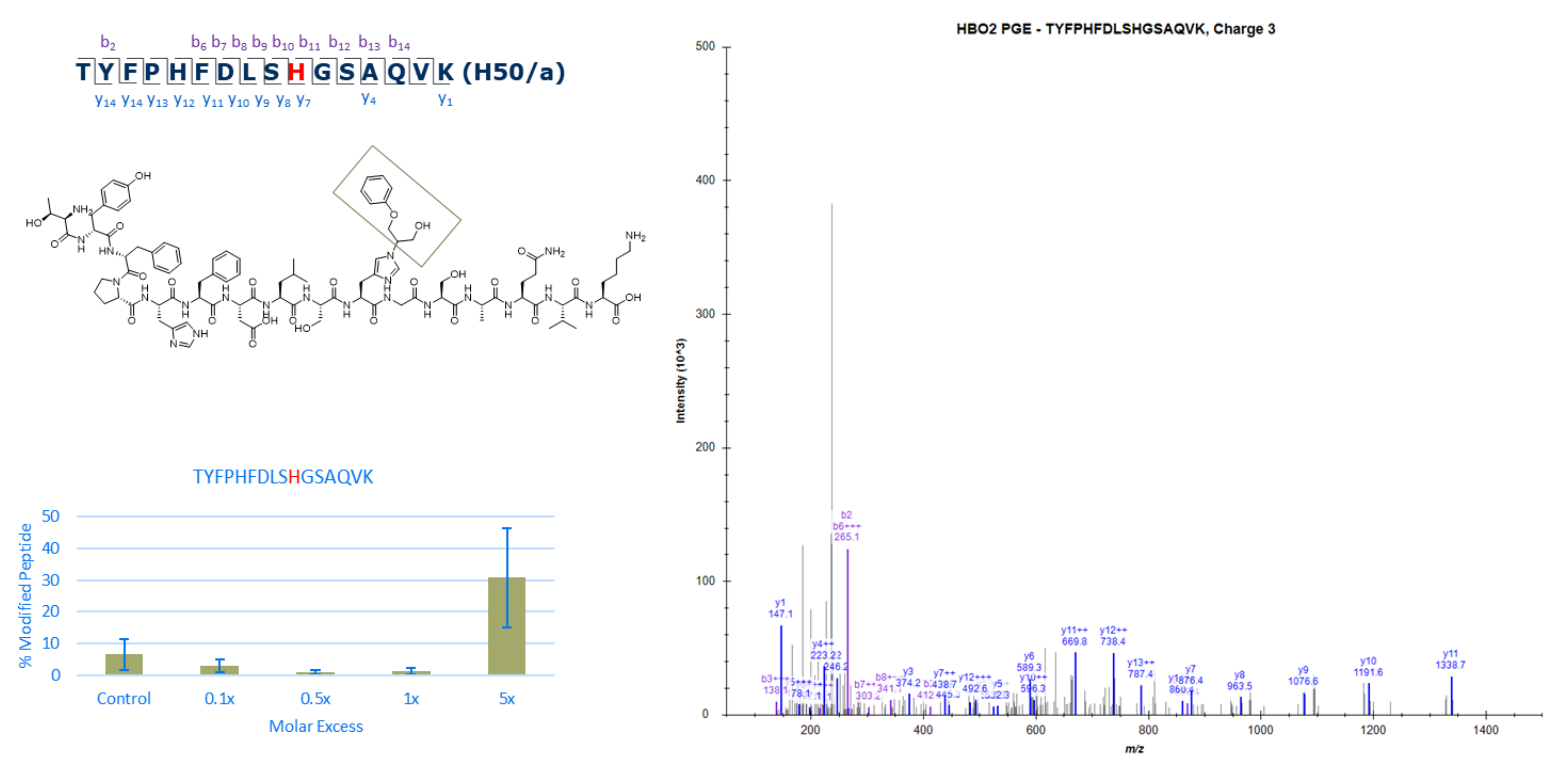

Figure S15. Tandem mass spectra, structure of the adducted peptide identified using PRM analysis, and relative estimation of the peptide containing the His50 site in subunit $\alpha$ of $\mathrm{Hb}$ modified by PGE.

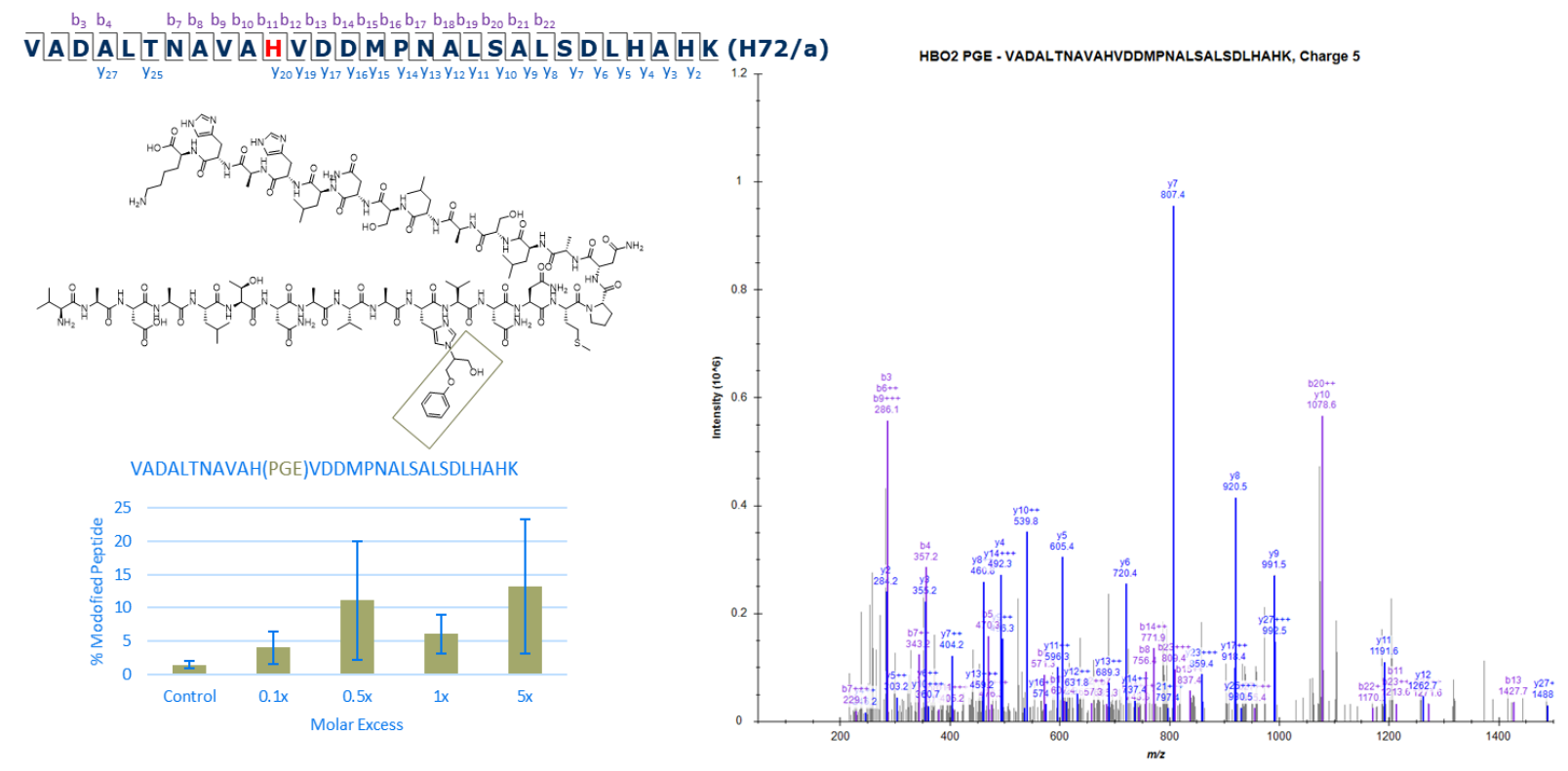

Figure S16. Tandem mass spectra, structure of the adducted peptide identified using PRM analysis, and relative estimation of the peptide containing the His72 site in subunit $\alpha$ of $\mathrm{Hb}$ modified by PGE. 

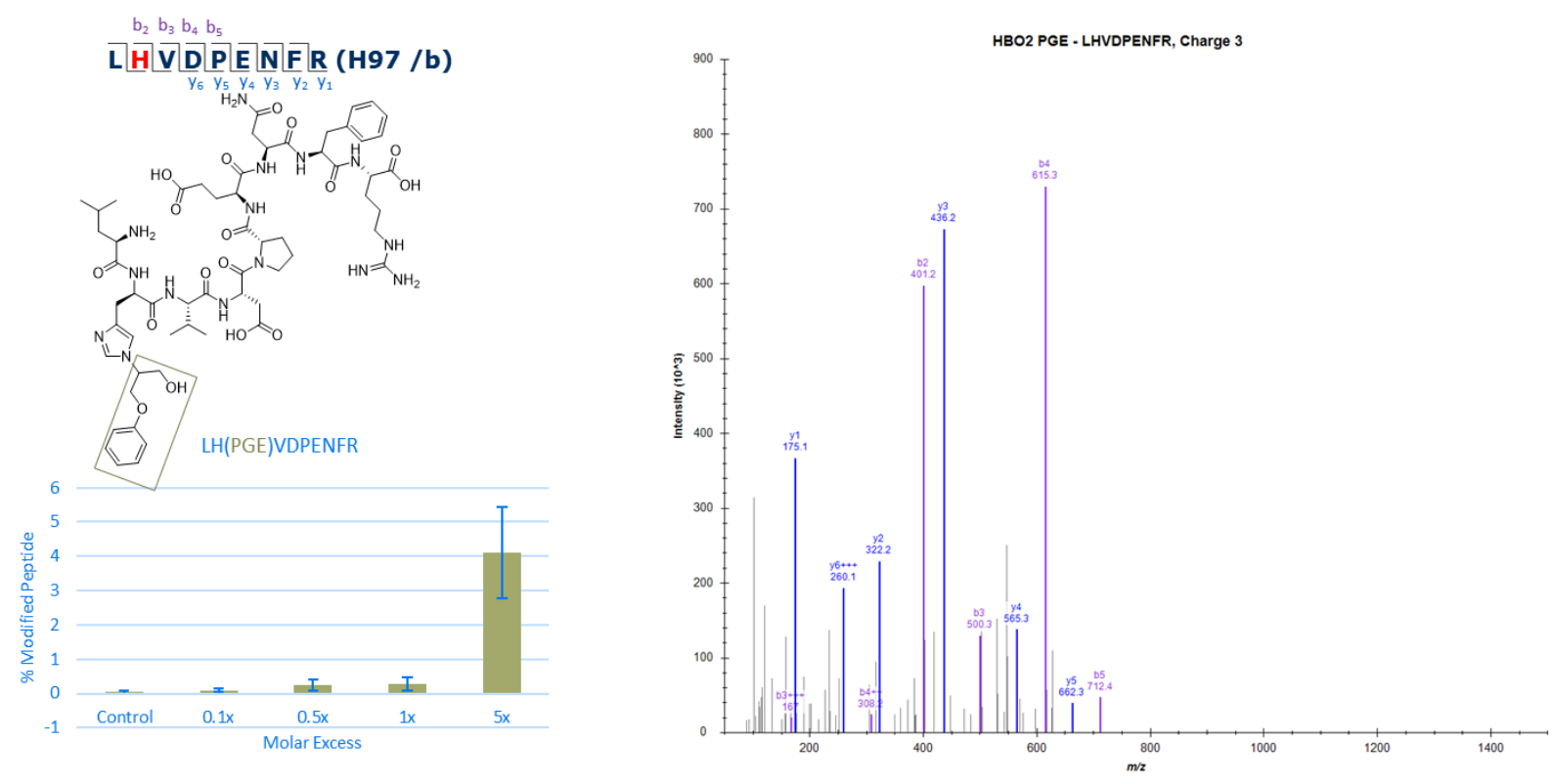

Figure S17. Tandem mass spectra, structure of the adducted peptide identified using PRM analysis, and relative estimation of the peptide containing the His97 site in subunit b of $\mathrm{Hb}$ modified by PGE.
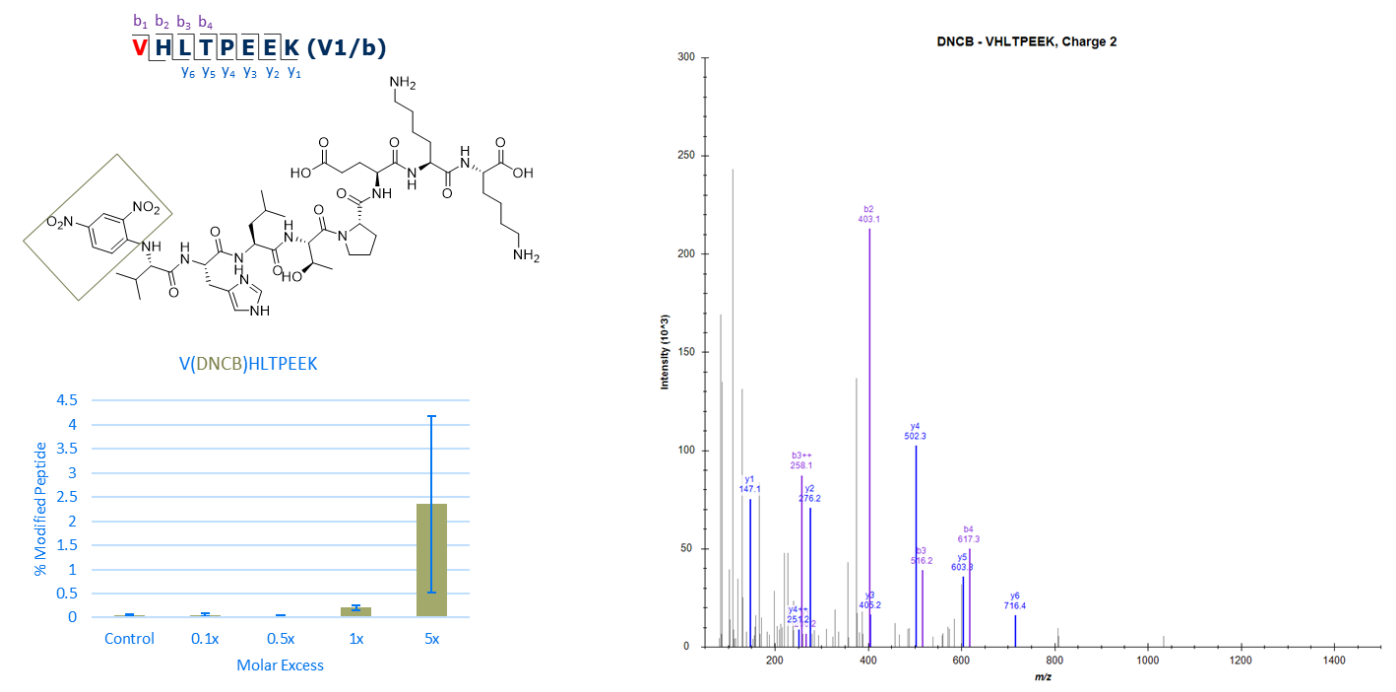

Figure S18. Tandem mass spectra, structure of the adducted peptide identified using PRM analysis, and relative estimation of the peptide containing the $\mathrm{Val}_{1}$ site in subunit $\mathrm{b}$ of $\mathrm{Hb}$ modified by DNCB. 


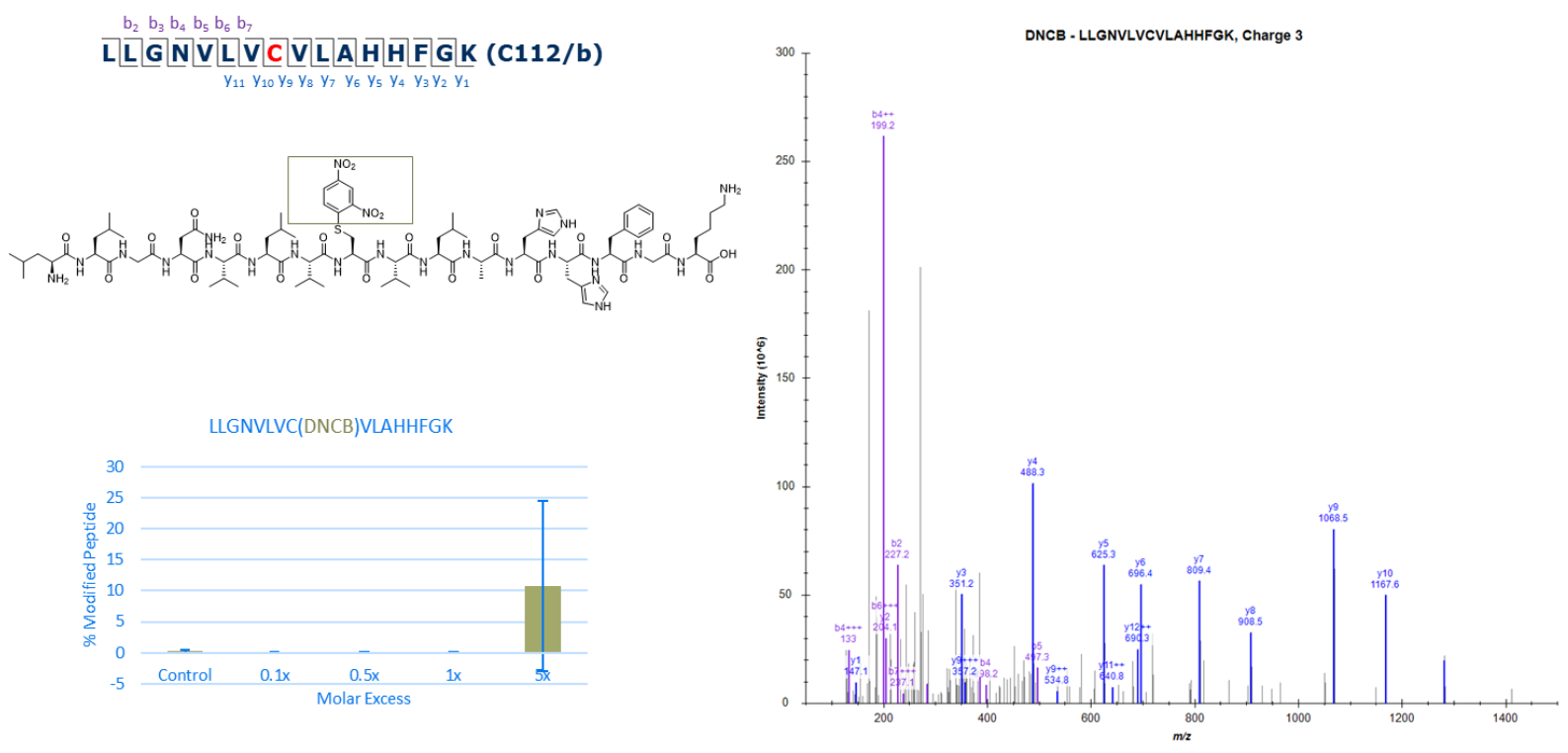

Figure S19. Tandem mass spectra, structure of the adducted peptide identified using PRM analysis, and relative estimation of the peptide containing the Cys 112 site in subunit b of $\mathrm{Hb}$ modified by DNCB. 
Protein Data Bank (PDB) structures of the adducted proteins

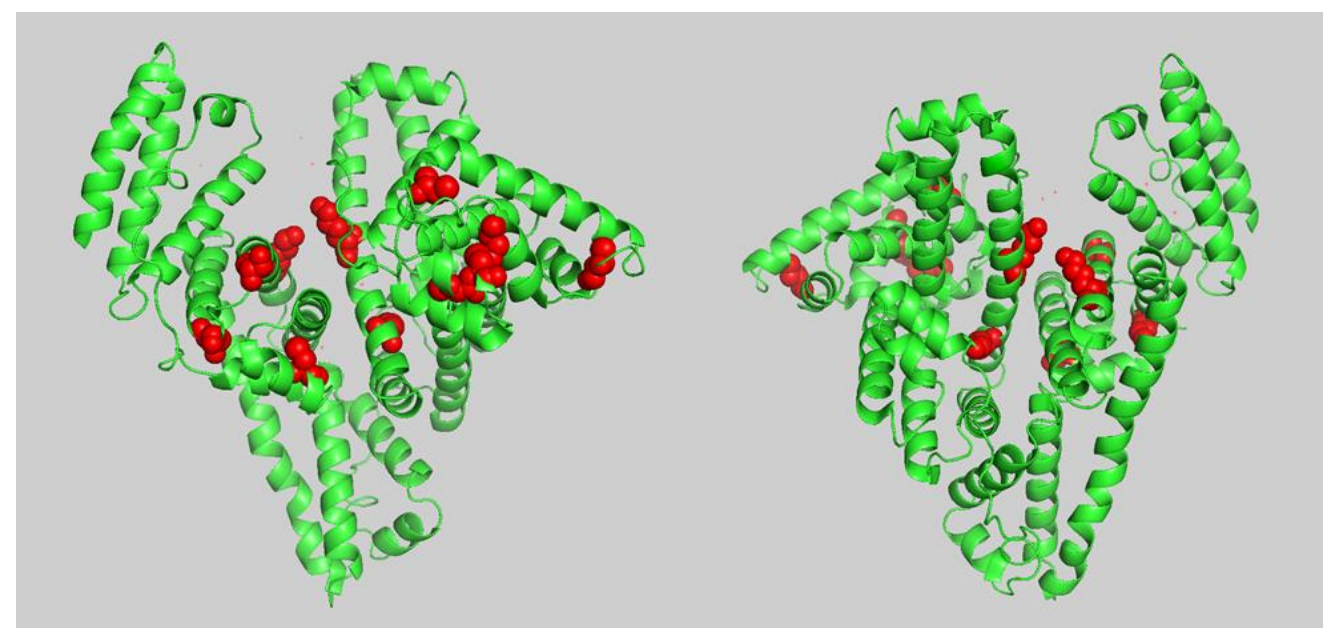

Figure S20. PDB structure of HSA front and back, with sites modified by DNCB highlighted in red.

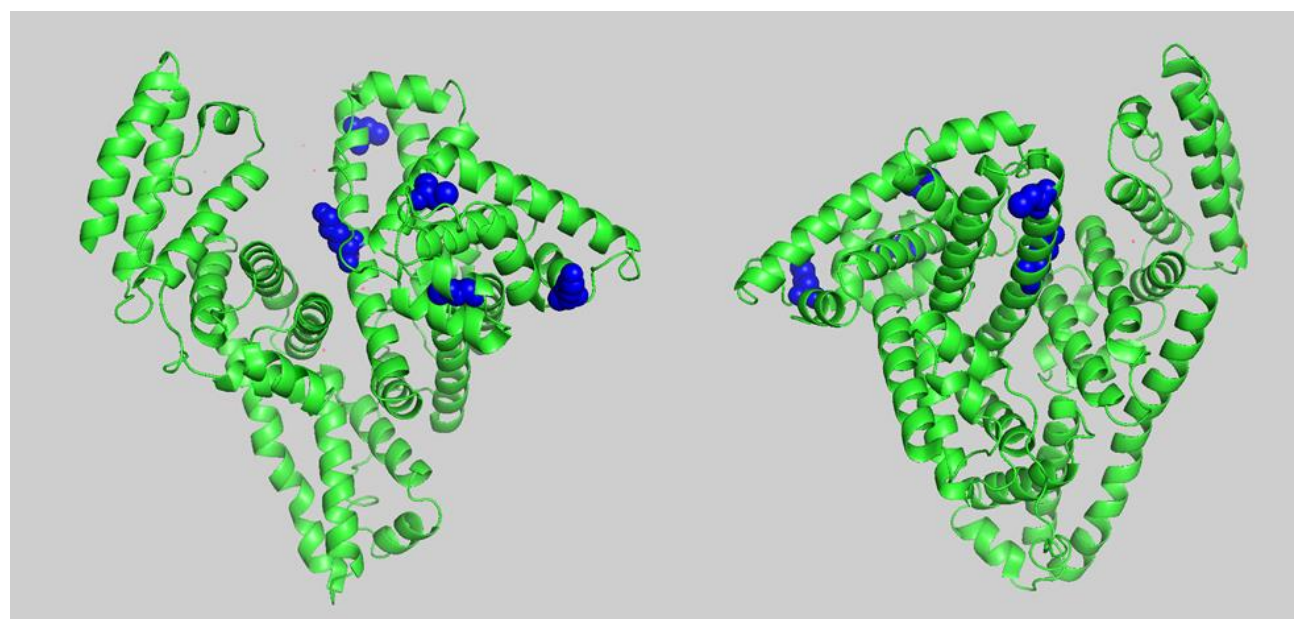

Figure S21. PDB structure of HSA front and back, with sites modified by PGE highlighted in blue. 


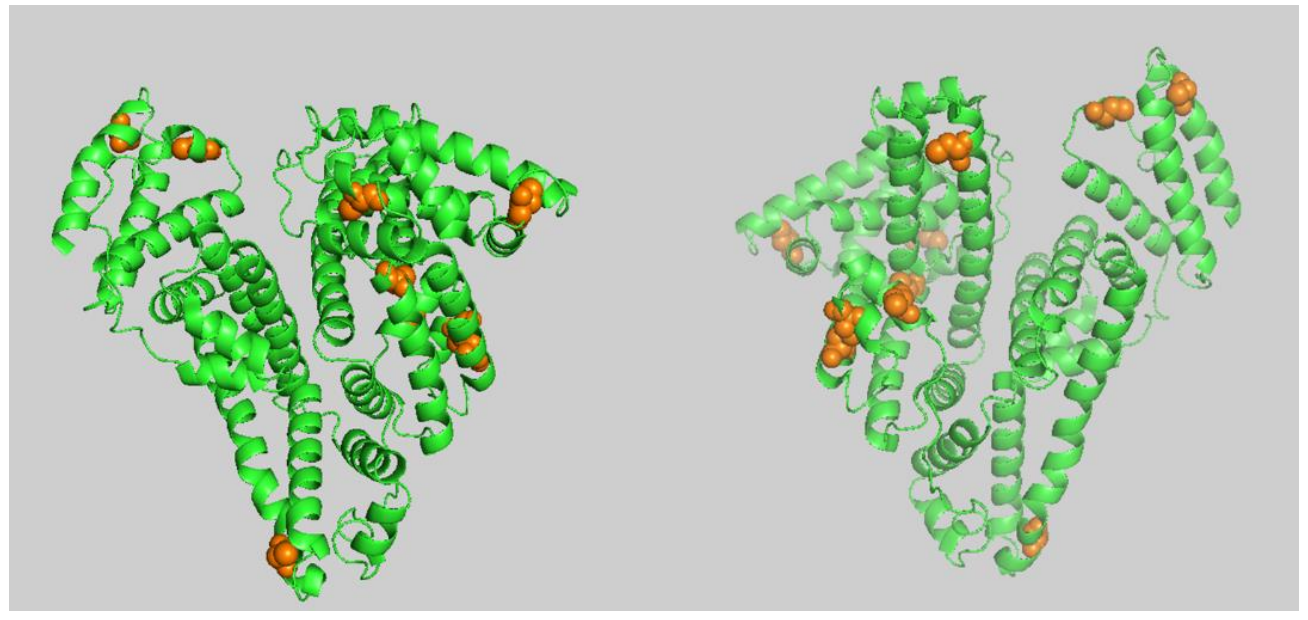

Figure S22. PDB structure of HSA front and back, with sites modified by MDBGN highlighted in orange.

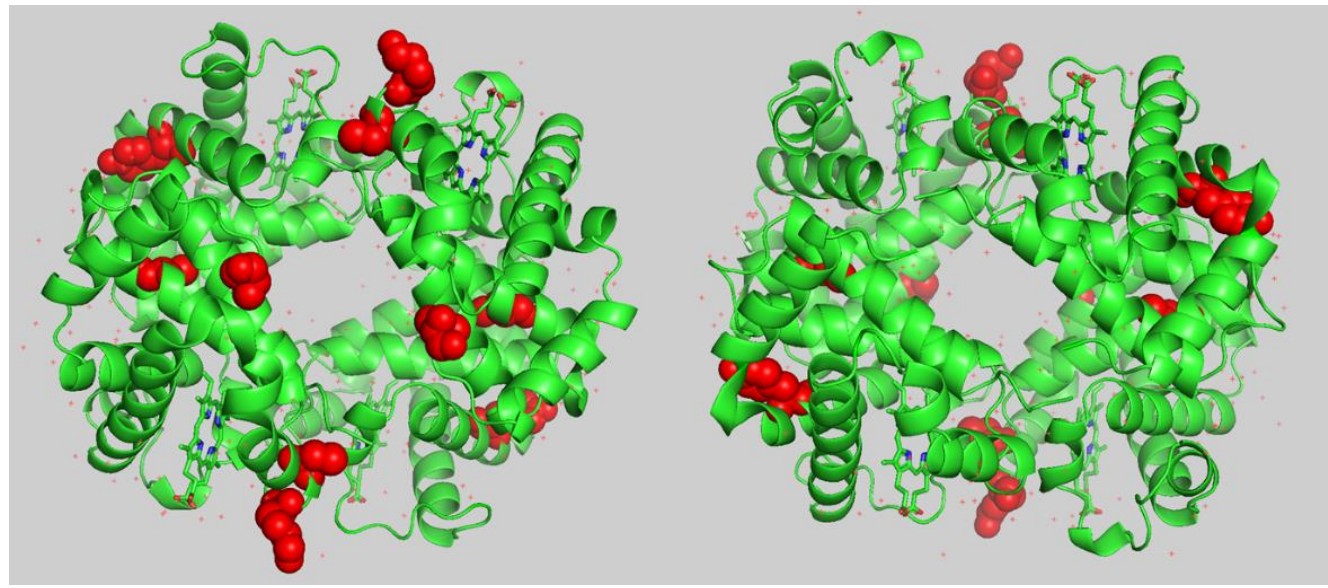

Figure S23. PDB structure of $\mathrm{Hb}$ front and back, with sites modified by DNCB highlighted in red. 


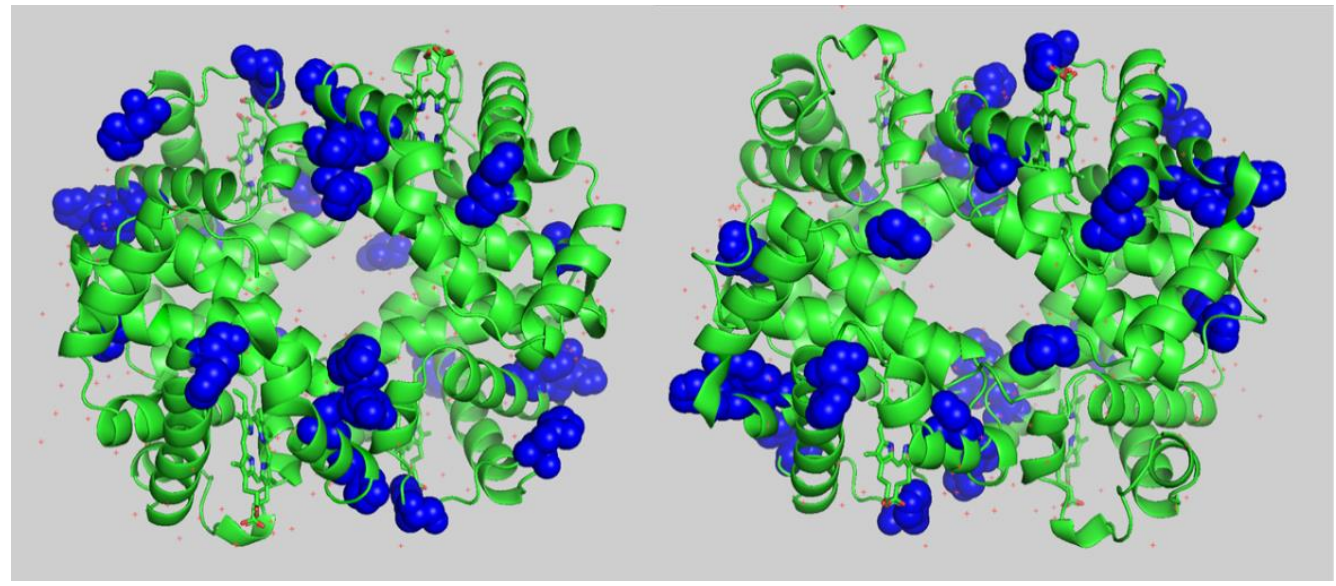

Figure S24. PDB structure of Hb front and back, with sites modified by PGE highlighted in blue. 